\title{
A Study on Retail Service Quality with Special Reference to Kanyakumari District
}

\author{
G.Rajesh Babu, \\ Assistant Professor, Department of Management Studies, C.S.I. Institute of Technology, Thovalai, Kanyakumari \\ District-629302. Tamil Nadu, India
}

\begin{abstract}
The key determinant of the business performance in service industry is the service quality. In this paper an attempt has been made to study the retail service quality in Kanyakumari District with the help of instrument. The instrument used to measure service quality is the one developed by Dalholkar et.al., (1996). This paper identifies five important dimensions in retail service quality as 'Personal Interaction', 'Reliability', 'Policy', 'Physical Assets' and 'Problem Solving'. The results reveal that retail outlets in Nagercoil and Marthandam are better in providing retail service quality than the retail outlets in other towns of Kanyakumari District. The important determinants of retail service quality gap among the customers is their level of education, occupation and age.
\end{abstract}

Key words : Service quality, Retail outlet, Service Quality Gap

\section{Introduction:}

In India, the sales in organized retail industry was about Rs.16,000 crores in 2001-02 and estimated that it will cross Rs.37,000 crores by the year 2007. The industry is growing at the rate of 18 to 20 per cent per annum (Darshan Parikh, 2002). There are over two million retailers from the street cart hawkers to more sophisticated retail chain of stores (Nathan 2001). In terms of reach of retail facilities, it is reported that at the national level there were 42 families per retail outlet in rural area and 14 families per retail outlet in urban area (Sarwade, 2000).

Retailing in India is gradually inching its way towards becoming the next boom industry. The retail area today is very different-the opportunities are in credible but exploiting them is extremely tough. The retail environment is changing more rapidly than ever before (Dabholkar, 1996). The Indian consumers are becoming knowledgeable and expect more of superior quality products and improved services. The trade is characterized by intensifying competition from both domestic and foreign companies. By that the retailer has to differentiate themselves from others to encounter the rivals in the market. The generally accepted retailing strategy for creating competitive advantage is the service quality (Humomel and Savith, 1988; and Reichheld and Sasser, 1990).

Based on the above aspects, the measurement tool is developed with 28 items for studying the mix of goods and services.

In this paper, an attempt has been made on the application on Dabholkar's (1996) retail service quality scale in measuring the gap between customer's expectations and their perceptions about the service quality of retail stores in Kanyakumari District. The reliability of the data is assessed through Cronbach alpha.

\section{Concept Of Retail Service Quality}

Service Quality is defined by Gronroos (1983) as the fulfilment of customer's expectations. Parasuraman et.al., (1985) defined service quality as the gap between customer's expectations of service and their perceptions of the service experience. Cronin and Taylor (1992) suggested that service quality is a vital antecedent of customer satisfaction. Parasuraman et.al., (1988) developed a twenty two item instrument recognized as SERVQUAL that has become widely used as a generic instrument of measuring service quality. Cronin and Taylor (1992) have examined a performance based measure of service quality, called SERVPERF in four industries.

In retail trade, Dabholkar et.al., (1996) proposed that retail service quality has a hierarchical factor structure. He identified a twenty eight item instrument to measure the service quality in retailing. Retail literature suggests that store appearance is important to retail customers (Baker et.al., 1994). In addition, the physical aspects such as store layout, parking facilities, furniture and fixtures add more consumer value (Oliver, 1981; and Hummel and Savitt, 1988). The Customerization and personalization are the important measurement to increase the reliability on the retail out (West brook, 1981). The problem solving, pricing and policy are the captured aspects of service quality in retailing (Dianne and Hornby, 1993; and Handler, 1996). 


\section{OBJECTIVES OF THE STUDY}

(i) To assess the important retail service quality dimensions;

(ii) To carry out the GAP analysis in various dimensions of retail service quality;

(iii) To analyse the significant difference among the five major towns in Kanyakumari District regarding the retail service quality dimensions

(iv) To reveal the association between the profile of customers and their retail service quality gap.

\section{Methodology}

Five major towns in Kanyakumari District namely Nagercoil, Thuckalay, Marthandam, Kaliakkavilai and Colachel have been purposively selected for the study. Five departmental stores from each town have been identified at the convenience of the researcher for this study. From each departmental store, 10 retail shoppers have been met by the researcher to collect the primary data about the retail service quality. The total sample size of the study comes to 250 . The sample consists of 62 per cent of females. Respondents are mostly between the ages of 20 and $45(71 \%)$. Close to one-half (53\%) are house wives. In total 61 per cent of the respondents are married. Almost 63 per cent of the respondents have been at least under graduates. Personal interviews are conducted immediately after the completion of the shopping experience. The appropriate statistical tools have been used to analyse the data in order to fulfill the objectives of the study.

\section{Results And Discussions}

To narrate the variables in retail service quality, the exploratory factor analysis has been administered. The perception and expectation score on 28 items in retail service quality are taken for the exploratory factor analysis. Initially the validity of data for factor analysis have been tested with the help of Kaiser-Meyer-Ohlin measure of sampling adequacy and Bartletts' test of sphericity. Both these tests satisfy the validity of data for factor analysis. The exploratory factor analyses have been executed to narrate the service quality variables into factors. The factor loading of the variables in retail service quality with it's factors, eigen value and the per cent of variation explained by the factors are shown in Table No.1.

TABLE No. 1

Factor Loading of the Variables in Retail Service Quality

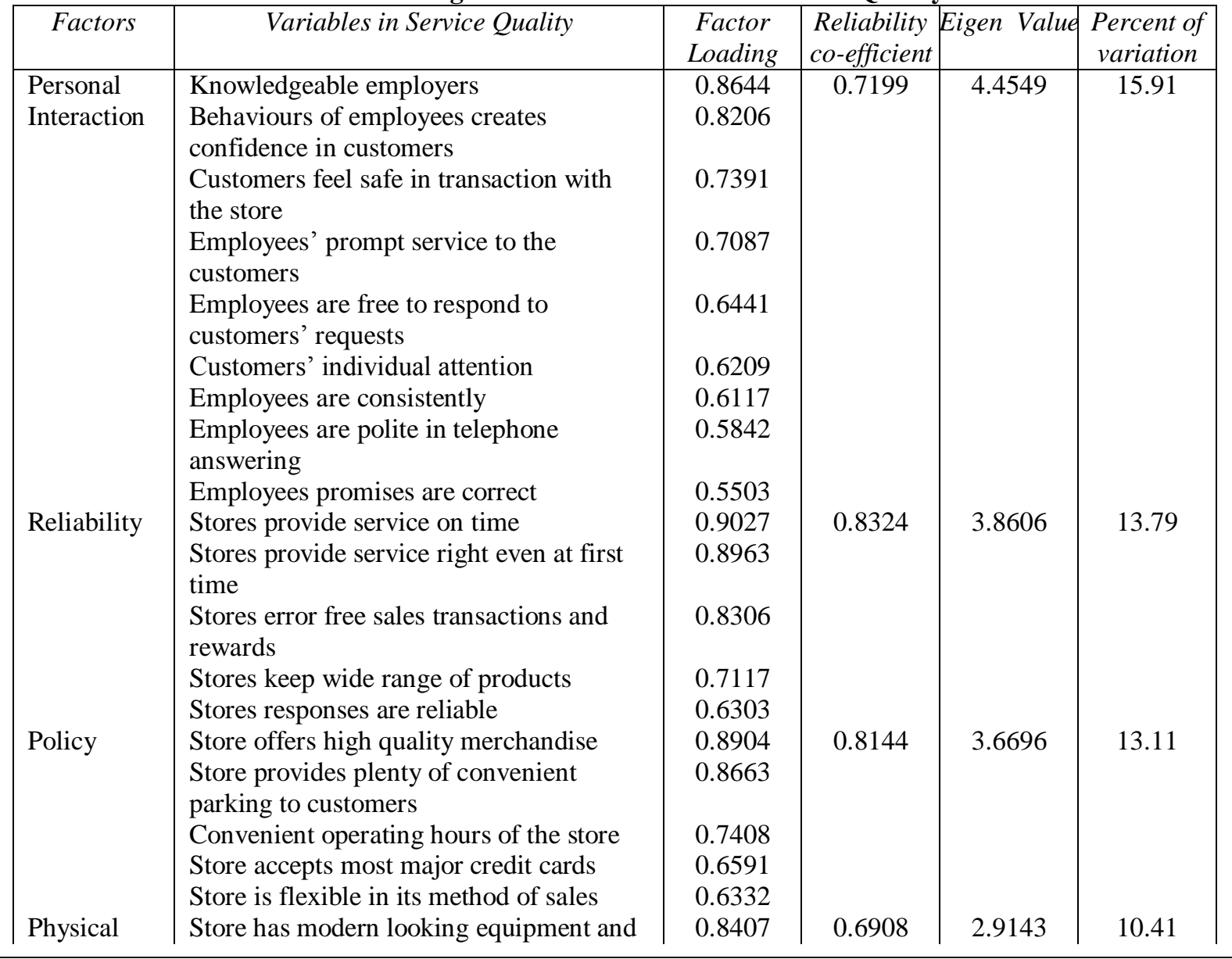




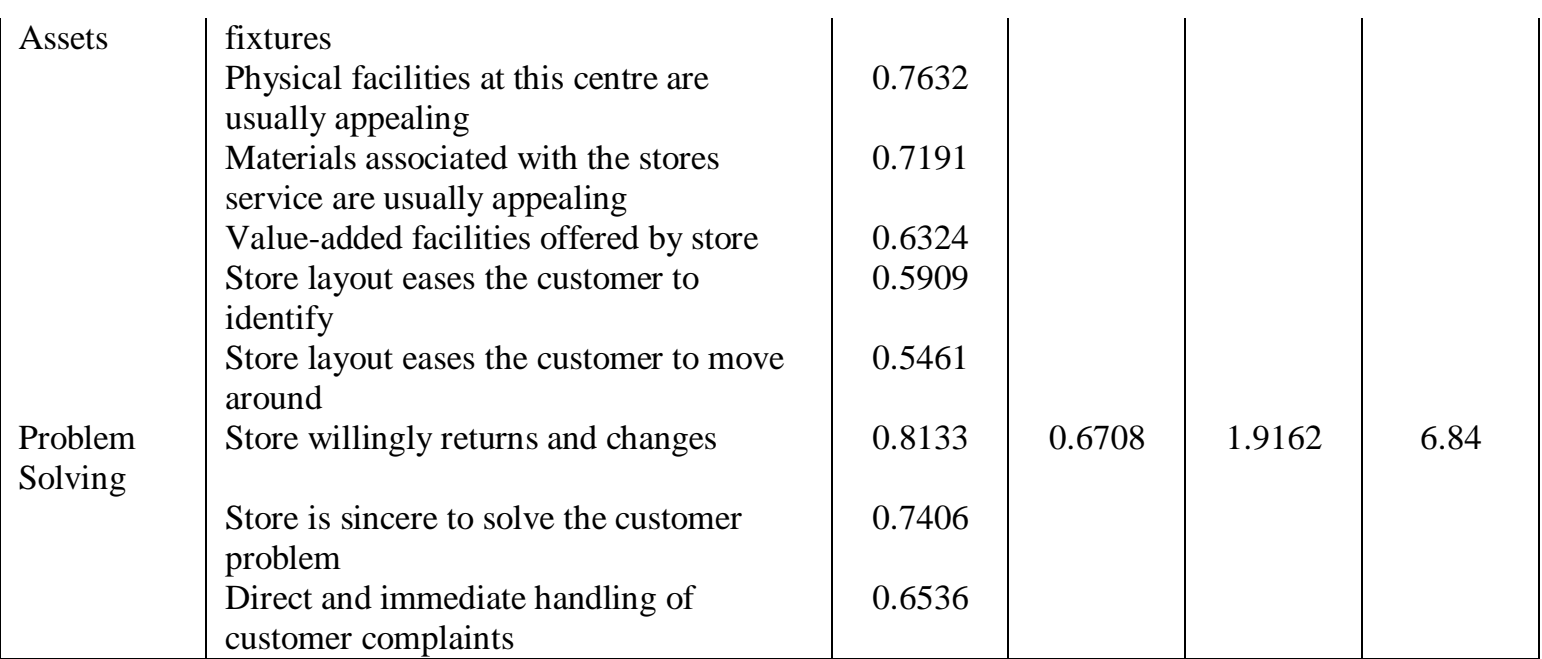

The factor analysis results in five important factors in retail service quality namely personal interaction, reliability, policy, physical assets and problem solving. The above said five factors explain the retail service quality to the extent of 60.06 per cent. The most important factor in retail service quality is personal interaction which consists of nine variables with the reliability co-efficient of 0.7199 . The eigen value and the per cent of variation explained by this factor are 4.4549 and 15.91 per cent respectively.

The next two important factors are 'reliability' and 'policy' which consist of five variables each with the reliability co-efficient of 0.8324 and 0.8144 respectively. The last two important factors are 'physical assets' and 'problem solving' which consist of six and three variables with the reliability co-efficient of 0.6908 and 0.6708 respectively. These five factors in retail service quality are taken for further analysis.

\section{RELIABILITY AND VALIDITY OF VARIABLES IN RETAIL SERVICE QUALITY}

The exploratory factor analysis identifies five important retail service quality namely personal interaction, reliability, policy, physical assets and problem solving. The variables in the above said five factors have been included for confirmatory factor analysis. It results in standardized factor loading of the variables in each retail service quality factor, its statistical significance, composite reliability and average variance extracted. The results are given in Table No. 2

TABLE No. 2

Reliability and Validity of Variables in Retail Service Quality

\begin{tabular}{|c|c|c|c|c|c|c|}
\hline Sl.No. & $\begin{array}{l}\text { Retail service } \\
\text { quality factors }\end{array}$ & $\begin{array}{l}\text { Number of } \\
\text { variables in }\end{array}$ & $\begin{array}{c}\text { Range of } \\
\text { standardized } \\
\text { factor loading }\end{array}$ & $\begin{array}{l}\text { Range of } \\
\text { 't' statistics }\end{array}$ & $\begin{array}{l}\text { Composite } \\
\text { reliability }\end{array}$ & $\begin{array}{c}\text { Average } \\
\text { variance } \\
\text { extracted (in } \\
\text { percent) }\end{array}$ \\
\hline 1. & $\begin{array}{l}\text { Personal } \\
\text { interaction }\end{array}$ & 9 & $\begin{array}{c}0.9147- \\
0.6239\end{array}$ & $\begin{array}{c}4.1189 *- \\
2.8917 *\end{array}$ & 0.6989 & 53.08 \\
\hline 2. & Reliability & 5 & $\begin{array}{c}0.8699- \\
0.6503\end{array}$ & $\begin{array}{c}3.6018^{*}- \\
2.4209 *\end{array}$ & 0.7635 & 54.11 \\
\hline 3. & Policy & 5 & $\begin{array}{c}0.9028- \\
0.6417\end{array}$ & $\begin{array}{c}4.0383^{*}- \\
2.3887^{*}\end{array}$ & 0.7804 & 56.02 \\
\hline 4. & Physical assets & 6 & $\begin{array}{c}0.8909 \\
0.6696\end{array}$ & $\begin{array}{l}3.9217 *_{-} \\
2.5891 *\end{array}$ & 0.6729 & 52.86 \\
\hline 5. & $\begin{array}{l}\text { Problem } \\
\text { solving }\end{array}$ & 3 & $\begin{array}{c}0.8244- \\
0.6776\end{array}$ & $\begin{array}{c}3.2491 *- \\
2.6907 *\end{array}$ & 0.6445 & 51.92 \\
\hline
\end{tabular}

The standardized factor loading of the variables in each retail service quality factor are greater than 0.60 which indicates the content validity. The significance of ' $t$ ' statistics of the standardized factor loading of the variables in each retail service quality factor represent its convergent validity. It is also confirmed by the composite reliability and average variance extracted since there are greater than its minimum threshold 0.80 and 50.00 per cent respectively. The analysis confirms the variable in each retail service quality factor is representing it in a reliable manner. The instrument could serve as a diagnostic tool for the further analysis.

\section{SERVICE QUALITY GAP ANALYSIS}

For evaluating the gap between the customers' perception and expectation on the retail service quality, the difference between the perception and expectation score on each factor in retail service quality have been 
computed. The perception and expectation score on five factors in retail service quality have been computed by the mean score on the perception and expectation score on the variables involved in each factor. In order to find out the significant difference between the mean of perception and expectation on each factor in retail service quality, the ' $t$ ' test have been applied. The results of service gap analysis are exhibited in Table No.3.

TABLE 3

Service Quality Gap in Retailing

\begin{tabular}{|c|c|c|c|c|c|}
\hline \multirow[t]{2}{*}{ Sl.No. } & \multirow[t]{2}{*}{ Factors in Service Quality } & \multicolumn{2}{|c|}{ Mean score on } & \multirow{2}{*}{$\begin{array}{c}\text { Service } \\
\text { quality gap } \\
(P-E)\end{array}$} & \multirow[t]{2}{*}{ T-Statistis } \\
\hline & & $\begin{array}{c}\text { Perception } \\
(P)\end{array}$ & Expectation (E) & & \\
\hline 1. & Personal interaction & 2.8142 & 3.3026 & -0.4884 & $-2.6742 *$ \\
\hline 2. & Reliability & 2.6068 & 3.1725 & -0.5657 & $-2.9963 *$ \\
\hline 3. & Policy & 2.8564 & 3.2697 & -0.4133 & $-2.3391 *$ \\
\hline 4. & Physical Assets & 2.5502 & 3.2036 & -0.6534 & $-3.3814^{*}$ \\
\hline 5. & Problem Solving & 2.9166 & 3.6968 & -0.7802 & $-3.9691 *$ \\
\hline
\end{tabular}

* Significant at 5 per cent level.

In all factors of retail service quality, the mean scores of expectation are greater than its perception. It reveals that the service quality gap is identified in all factors of the retail service quality which are statistically significant also. The higher service gaps are identified in factors namely problem solving and physical assets since the respective service quality gaps are -0.7802 and -0.6534 . The analysis infers that the retail service quality is not upto to the expectation of the customers.

\section{SERVICE QUALITY GAP IN VARIOUS TOWNS}

The study includes five major towns in Kanyakumari District which highly differ in location, standards of living and the consumption pattern of the people. It is highly imperative to analyse the service quality gap in various town to understand the way in which the customers differ in the above five towns in order to formulate the suitable retail marketing strategies. The computed service quality gap in the five cities and its respective ' $F$ ' statistics are presented in Table No. 4.

TABLE No. 4

Service Quality Gap in Various Cities

\begin{tabular}{|c|l|c|c|c|c|c|c|}
\hline Sl. & Factors in & \multicolumn{7}{|c|}{ Service Quality Gap in } & $\begin{array}{c}F- \\
\text { No. }\end{array}$ & $\begin{array}{l}\text { Service } \\
\text { Quality }\end{array}$ & & Nagercoil & Thuckalay & Marthandam & Kaliakkavilai & Colachel & $\begin{array}{c}\text { Statistic } \\
\text { S }\end{array}$ \\
\hline 1. & $\begin{array}{l}\text { Personal } \\
\text { interaction }\end{array}$ & 0.3862 & -0.7357 & 0.2863 & -1.0446 & -1.3342 & - \\
2. & Reliability & -0.4630 & -0.8789 & 0.2117 & -0.8341 & -0.8642 & $5.8648^{*}$ \\
3. & Policy & 0.2070 & -0.3391 & -0.3102 & -0.5134 & -1.1108 & $6.9617^{*}$ \\
4. & Physical & 0.3062 & -1.2649 & 0.2964 & -1.2961 & -1.3086 & $9.0843^{*}$ \\
& Assets & & & & & & \\
5. & Problem & -1.3131 & -0.8324 & 0.0774 & -0.9226 & -0.9103 & 4.4748 \\
& Solving & & & & & & \\
\hline
\end{tabular}

$\mathrm{F}(4,94)$ at 5 per cent level 2.34 .

In Nagercoil, the service quality gaps are identified in the reliability and problem solving since the respective scores are -0.4630 and -1.3131 . In Thuckalay, Kaliakkavilai and Colachel, the service quality gaps are identified in all five dimensions of retail service quality since the respective service quality scores are in negative. The Marthandam town is better than all other towns, since the negative service quality gap is identified only in policy. There is a significant difference among the five towns regarding the service quality gap in personal interaction, reliability, policy and physical assets since the respective ' $F$ ' statistics are significant at five per cent level. The analysis infers that the retail service quality is better in Marthandam and Nagercoil. The weakest dimensions of the retail service quality in Nagercoil are 'Problem Solving' and 'Reliability' whereas in Marthandam, it is only 'Policy'.

\section{Association between Profile of Customers and their Service Quality Gap}

The service quality gap may arise at different degrees on various service quality dimensions. It is the outcome of the different between mean of perfection and expectations on various retail service quality among the customers. The expectations and perception are highly determined by the profile of the customers. Hence the present study has made an attempt to analyse the association between the profile of customers and their service quality gap. The included profile variables are sex, age, marital status, occupation and level of education. These 
are classified into 2, 5, 4, 6 and 6 groups respectively on the basis of the above profile variables. In order to analyse the significant difference among the customers classified on the basis of their profile regarding their retail service quality gap, the one way analysis of variance has been used. The results are presented in Table No.5.

TABLE No.5

Service Quality Gap among Customers with Different Profile

\begin{tabular}{|c|c|c|c|c|c|c|}
\hline \multirow{2}{*}{$\begin{array}{l}\text { Sl. } \\
\text { No. }\end{array}$} & \multirow{2}{*}{$\begin{array}{c}\text { Factors in Service } \\
\text { Quality }\end{array}$} & \multicolumn{5}{|c|}{ F-Statistics } \\
\hline & & Sex & Age & $\begin{array}{c}\text { Marital } \\
\text { Status }\end{array}$ & Occupation & $\begin{array}{l}\text { Level of } \\
\text { Education }\end{array}$ \\
\hline 1. & Personal interaction & $4.1082 *$ & $2.8601 *$ & $2.7102^{*}$ & $2.4581 *$ & $2.4806^{*}$ \\
\hline 2. & Reliability & 1.9624 & $3.0219 *$ & $3.1161 *$ & $2.9606^{*}$ & $3.1146^{*}$ \\
\hline 3. & Policy & 1.2038 & 1.9887 & 2.0686 & $2.3302 *$ & $2.9091 *$ \\
\hline 4. & Physical Assets & 2.4004 & $2.6083 *$ & 1.8234 & 1.7183 & $2.8606^{*}$ \\
\hline 5. & Problem Solving & 3.0671 & $2.5142 *$ & 1.4081 & $2.5406^{*}$ & $2.4649 *$ \\
\hline
\end{tabular}

* Significant at 5 per cent level.

Regarding sex among the customers, the significant difference in service quality gap is identified only in 'Personal Interaction' since its ' $F$ ' statistics is significant at five per cent level. The age is the important criterion variable on the service quality gap in all retail service quality factors except policy. By marital status, the significant differences among the customers are identified especially in the retail service quality namely 'personal interaction' and 'Reliability'. Regarding the occupational category the significant differences are identified in the service quality of 'personal interaction', 'reliability', 'policy' and 'problem solving'. The profile variable namely level of education is significantly associating with the service quality gap in all five dimensions of retail service quality. The analysis infers that the profile variables namely level of education; occupation and age play an important role in the perception and expectation on the retail service quality among the customers.

\section{SUGGESTIONS FOR IMPROVEMENT IN RETAILING}

Based on the findings of the study, the following policy implications are drawn: Since the service quality gap in all dimensions are almost in negative, the retailers have to analyse the customer's expectations and perceptions on retail service quality consistently. They are advised to take remedial action to minimize such gaps according to their resources.

The remedial measures to minimize the service quality gap in different towns need not be the same. In Thuckalay, Kaliakkavilai and Colachel, the retailers have to focus on all five dimensions in retail service quality. In Marthandam, the retailers are advised to fill up the gap in 'policy' alone whereas in Nagercoil, these areas are reliability and problem solving. The employees in retail counters should be properly trained to improve their skills in personal interaction, reliability and problem solving.

The retailers in Thuckalay, Kaliakkavilai and Colachel are very weak in the dimension of 'Physical assets'. They may be advised to visit the retail counters at Marthandam and Nagercoil in order to minimize the service quality gap especially in physical assets.

\section{Conclusion}

The application of Dabholkar et.al., (1996) model in measuring retail service quality in Kanyakumari District is a base for the study. It is event from the study, the 28 items in retail service quality are narrated into five important dimensions as proposed by Dabholkar et.al., (1996). The study concludes that there is a service quality gap in all five dimensions in few towns of Kanyakumari District namely Thuckalay, Kaliakkavilai and Colachel. The study also revealed that the profile variables namely level of education; occupation and age play an important role in service quality gap. This service quality gap analysis guides the retailers in Kanyakumari District to improve their service quality at their retail counters. Since the study is related to retail service quality, it is highly dynamic. Hence, the retailers should be very cautious to analyse their customers' perceptions and expectation in a consistent manner in order to enrich their business in future.

\section{References:}

[1]. Baher, J., Grewal, D. and Prasuraman, A., (1994), "The Inference of store environment of on quality interferences and store image", Journal of Academy of Marketing Science 22 (Fall), pp.328-339.

[2]. Cronin, J.J., and S.A.Taylor, (1992), "Measuring Service Quality: a re-examination and extension", Journal of Marketing, 56 (3), pp.55-68.

[3]. Cunningham, Dianne and Winn Hornby (1993), "Pricing decision in Small farms: Theory and Practices", Management decisions, 31(7), pp.46-55. 
[4]. Dabholkar, P.A., Thorpe, DI and Dentz, J.O. (1996), “A measure of Service Quality for retail stores: Scale Development and validation", Journal of Academy of Marketing Science, 24(1), pp.3-16.

[5]. Darshan Parik, (2002), "Measuring Retail Service Quality: An Emprical Study in a developing Country", South Asian Journal of Management, 12(2), April - June, pp.43-57.

[6]. Reichheld, F.F., and Sasser, Jr., W.C, (1990), "Zero Defections: Quality Comes to Services", Harward Business Review, 68(5), pp.105-111.

[7]. Gronroos, C., (1983), "Strategic management and marketing in the service sector", Marketing Science Institute, Cambridge, M.A..

[8]. Handler, Douglas, P., (1996), "Pricing Strategies becoming Crucial", Super Market Business, September, 28.

[9]. Hummel, J.W. and Savitt, R., (1988), "Integrated customer service and Retail strategy", International Journal of Retailing, 3(2), pp.5-21.

[10]. Oliver, R., (1981), "Measurement and Evaluation of Satisfaction Processes in Retail Settings", Journal of Retailing, 57(Fall), pp.2548.

[11]. Parasuraman, A., V.A. Zeithaml an L.C. Berry (1985), "A conceptual model of service quality and its implications for future research", Journal of Marketing, 49 (Autumn), pp.41-50

[12]. Parasuraman, A., V.A., Zeithaml and L.C. Berry (1988), "SERVQUAL: A multi item scale for measuring customer perceptions of service quality", Journal of retailing, 64 (Spring), pp.12-40.

[13]. Sarwade, W.K., (2000), "Retail trade structure in Rural India", Indian Journal of Marketing, 30 (8-10), August - October, pp.26-35.

[14]. West Brook, R.A., (1981), "Sources of Consumer satisfaction with retail outlets", Journal of retailing, 57 (Fall), pp.68-85. 